\title{
Biological activity of sponge-associated fungi from Karimunjawa Islands, Indonesia against pathogenic Streptococcus pneumoniae
}

\author{
OLVI CRISTIANAWATI ${ }^{1,2}$, ANINDITIA SABDANINGSIH ${ }^{1,3}$, LEONTINE ELISABETH BECKING $^{4}$, \\ MIFTAHUDIN MAJID KHOERI ${ }^{5}$, HANDUNG NURYADI ${ }^{6}$, AGUS SABDONO $^{7}$, AGUS TRIANTO ${ }^{7, \bullet}$, \\ OCKY KARNA RADJASA ${ }^{7,8}$ \\ ${ }^{1}$ Coastal Resources Management, Universitas Diponegoro. Semarang 50241, Central Java, Indonesia \\ ${ }^{2}$ The Center for Coastal Rehabilitation and Disaster Mitigation Studies, Universitas Diponegoro. Semarang 50275, Central Java, Indonesia \\ ${ }^{3}$ Department of Aquatic Resources, Faculty of Fisheries and Marine Sciences, Universitas Diponegoro, 50275, Semarang, Central Java, Indonesia \\ ${ }^{4}$ Department of Marine Animal Ecology, Wageningen University. Wageningen, NL-6700, AA, The Netherlands \\ ${ }^{5}$ Eijkman Institute for Molecular Biology. Jakarta 10430, Indonesia \\ ${ }^{6}$ Graduate School of Engineering and Science, University of The Ryukyus. 1 Senbaru, Nishihara, Okinawa 903-0213, Japan \\ ${ }^{7}$ Department of Marine Science, Universitas Diponegoro. Jl. Prof. H. Soedarto, S.H., Tembalang, Semarang 50275, Central Java, Indonesia. \\ Indonesia. Tel.: +62-24-7474698, Fax.: +62-24-7474698, `email: agustrianto.undip@gmail.com \\ ${ }^{8}$ Directorate of Research and Public Services, Ministry of Research, Technology and Higher Education. Jakarta 10340, Indonesia
}

Manuscript received: 12 June 2019. Revision accepted: 12 July 2019.

\begin{abstract}
Cristianawati O, Sabdaningsih A, Becking LE, Khoeri MM, Nuryadi H, Sabdono A, Trianto A, Radjasa OK. 2019. Biological activity of sponge-associated fungi from Karimunjawa Islands, Indonesia against pathogenic Streptococcus pneumoniae. Biodiversitas 20: 2143-2150. Threats of drug-resistant Streptococcus pneumoniae and the urgent need for new antibiotics require prompt and sustained action for discovering bioactive compounds. This study aimed to isolate sponge-associated fungi as a candidate for sources of drugs. The sponge-associated fungi were screened against the MDR S. pneumoniae. The Deoxyribonucleic Acid (DNA) of fungal isolates that showed the most active was generated by using universal primers ITS1 and ITS4. While the sponge host was identified based on the molecular and by slide section. Out of twenty-nine fungal isolates from 13 marine sponges, S.06.2 isolate produced secondary metabolite that inhibiting the growth of MDR S. pneumoniae. Molecular identification based on the ITS region revealed that the active fungal isolate was closely related to Curvularia lunata, with a 99\% similarity. The C. lunata S.06.2 was isolated from sponge Cinachyrella australiensis. Thus, C. lunata S.06.2_ LC315806 can serve as a fruitful strategy for the discovery of novel antibiotics for the treatment of MDR S. pneumoniae.
\end{abstract}

Keywords: Cinachyrella australiensis, Curvularia lunata, Streptococcus pneumoniae, marine derived-fungi

\section{INTRODUCTION}

Indonesia is the global epicenter of marine biodiversity and harbors the majority of the earth's aquatic species (von Rintelen et al. 2017). Evidence has emerged, demonstrating that many natural products extracted from marine animals and algae are the products of associated microorganisms, mostly bacteria, and fungi (Raghukumar 2008). Spongeassociated fungi have the potential to produce new chemical entities (Volgraf et al. 2008; Blunt et al. 2010; Vasanthabharathi 2012; Vicente et al. 2013; Bolanos et al. 2015; Imhoff 2016; Indraningrat et al. 2016) that actively inhibited the growths of various pathogenic microorganisms (Khoeri et al. 2011; Mayer et al. 2013; Radjasa et al. 2013; Buttachon et al. 2016; Corral et al. 2018). Our previous research also showed that spongeassociated fungi have several bioactivities such as anti- $S$. aureus and E. coli (Wittriansyah et al. 2016), antibacterial produced by sponge Agelas sp. associated fungi Fusarium solani (Trianto et al. 2017), and Sibero (2019) has also reported that sponge-associated fungi from a mangrove habitat were producing anti-microbial activities.

Streptococcus pneumoniae, a gram-positive bacteria (Kadioglu et al. 2008), is a facultative anaerobic pathogen
(Hajaj et al. 2017) that is normally found in the human upper respiratory tract. This multidrug-resistant (MDR) bacteria may cause pneumonia, sepsis, meningitis, otitis media (O'Brien et al. 2009; Mirza et al. 2011; Hu et al. 2016; Cherazard et al. 2017), bloodstream infections and sinus infections in young children (CDC 2017). In Indonesia research on people with pneumococcal infection has already been carried out in the following areas: Jakarta (Yuliarti et al. 2012), Bandung, Central Lombok, and Padang West Sumatera (Dunne et al. 2018). The prevalence of carriers of $S$. pneumoniae among the healthy population has been sharply increasing (DKP-Jateng 2014; Farida et al. 2014; Ditjen P2P 2018) and multidrugresistant bacteria can pose a growing threat to general health (Lestari et al. 2012).

The prevalence of $S$. pneumoniae infections in Indonesia is considerably high, especially among children and the elderly. This study focuses on sponge-associated fungi with the capability of producing compounds with anti-S. pneumoniae properties, collected from the Karimunjawa Islands in the North Java Sea of Indonesia. 


\section{MATERIALS AND METHODS}

\section{Sponge sample collection}

The sponge samples were collected from six sites in the Karimunjawa Islands in the North Java Sea of Indonesia in March 2017 (Figure 1) through SCUBA diving. A total of 13 sponges were collected and stored in sterile plastic bags (Whirl-Pak, Nasco, USA) containing $50 \mathrm{ml}$ of seawater and were immediately placed in a cooling box at temperatures below $4{ }^{\circ} \mathrm{C}$ (Trianto et al. 2017). Half of each sample was preserved in $70 \% \mathrm{EtOH}$ as a voucher (Cleary et al. 2013).

\section{Isolation of sponge-associated fungi}

Sponge-associated fungi were isolated in accordance to Strobel and Daisy (2003 ) Using a sterile scalpel, the tissue of the sponges was cut in pieces of approximately $0.1 \mathrm{~cm}^{3}$ in size and sprayed three times with sterilized seawater. These pieces were then rinsed for surface sterilization with sterilized seawater and $70 \%$ EtOH. MEA medium (HiMedia $^{\mathrm{TM}}$, Mumbai, India) containing chloramphenicol antibiotics $(100 \mathrm{mg} / \mathrm{mL})$ was used for placing the sponge tissue in an incubator where it stayed at $28^{\circ} \mathrm{C}$ for seven days. Morphologically different colonies were separated and purified.

\section{Screening for antagonistic activity against pathogenic Streptococcus Pneumoniae}

Antimicrobial activity was determined through the agar plug method (Rahaweman et al. 2016; Sibero et al. 2017). Fresh and pure cultures of Streptococcus pneumoniae (RIN1) and American Type Culture Collection (ATCC), obtained from the culture collection from the EIJKMAN Institute for Molecular Biology in Jakarta, were diluted to a suspension equivalent to the $0.5 \mathrm{McFarland}$ standard. The suspension was spread over the entire area of a Mueller Hinton susceptibility agar plate $\left(\right.$ Oxoid $^{\mathrm{TM}}$, Basingstoke, UK) using a sterile cotton swab. Single tablets of fungi were placed on the inoculated agar plate, ensuring sufficient space between individual tablets to allow for proper measurements of inhibition zones. The plates were then incubated at $35^{\circ} \mathrm{C}$ for 18 hours (overnight).

\section{Cultivation and extraction of the active fungus}

One potentially active fungal isolate, namely S.06.2, was cultivated at a larger scale, using $1,000 \mathrm{ml}$ sterile bottles (Schott Duran, Germany), each containing $200 \mathrm{ml}$ of Malt Extract Broth (MEB) (HiMedia ${ }^{\mathrm{TM}}$ ) for 21 days at $27^{\circ} \mathrm{C}$. Subsequently, the fungal culture was filtered through filter paper (Advantec 7, Ø $125 \mathrm{~mm}$ ) to separate mycelia and media. The medium was mixed with organic solvent MEB: $E t O A c=1: 2(\mathrm{v} / \mathrm{v})$. A separation funnel was used to separate medium and organic solvent. The organic solvent containing compounds that were secreted by the fungi was then evaporated using a rotary evaporator (Eyela ${ }^{\circledR} \mathrm{N}$ 101, Tokyo, Japan) at $37^{\circ} \mathrm{C}$.

\section{In vitro antibacterial assay of fungal extract}

MH (Oxoid ${ }^{\mathrm{TM}}$ ) and MEB (HiMedia ${ }^{\mathrm{TM}}$ ) were used to cultivate the test bacteria and fungi, respectively. The cultures of S. pneumoniae were kept at $37^{\circ} \mathrm{C}$ overnight at under 5\% $\mathrm{CO}_{2}$ (Safari et al. 2015). The bacterium was diluted in a sterile $0.86 \%$ saline solution to obtain a cell suspension of $105 \mathrm{CFU} / \mathrm{mL}$. The disc diffusion method was used for the assay. $0.1 \mathrm{~mL}$ Of diluted inoculum (105 $\mathrm{CFU} / \mathrm{mL}$ ) of test organism was spread on $\mathrm{MH}$ agar plates. Sterile paper discs $\left(\varnothing 6 \mathrm{~mm}\right.$ Oxoid $^{\mathrm{TM}}$ ) impregnated with $100 \mu \mathrm{g}$ of compounds in $15 \mu \mathrm{L}$ ethyl acetate were used for the assay. A disc without any compound was used as a negative control. Chloramphenicol antibiotics $(30 \mu \mathrm{g}, \varnothing 6$ $\mathrm{mm}$ Oxoid $^{\mathrm{TM}}$ ) were used in the assay functioning as positive controls. Afterward, the plates were incubated in a $\mathrm{CO}_{2}$ incubator for 24 hours at $37^{\circ} \mathrm{C}$. Finally, the presence of a clear zone indicated antibacterial activity.

\section{Molecular identification of the active fungal isolate S.06.2}

Total DNA from mycelia was extracted using a Cheelex extraction method (Cristianawati et al. 2017, Qiu et al. 2005, Sibero et al. 2017). The internal transcribed spacer (ITS) region was amplified by using universal primer ITS 1 (5'-TCCGTAGGTGAACCTGCGG-3') and ITS 4 (5'TCCTCCGCTTATTGATATGC-3') (Macrogen Inc., Seoul, Korea) (Sabdaningsih et al. 2017). The polymerase chain reaction (PCR) was carried out in a thermal cycler (T100 TM Thermal Cycler, Bio-Rad Laboratories, California, USA). The PCR was done in volumes of $25 \mu \mathrm{L}$ consisted of $12.5 \mu \mathrm{L}$ of GoTaq ${ }^{\circledR}$ Green Master mix (Promega, Madison, USA), 9.5 $\mu \mathrm{L}$ of nuclease-free water, $1 \mu \mathrm{L}$ of extracted DNA template from the sponge-associated fungi and $1 \mu \mathrm{L}$ each of $10 \mu \mathrm{M}$ concentrations of the forward and reverse primer. PCR cycles were then preheated at $95^{\circ} \mathrm{C}$ for 3 minutes, followed by 30 cycles of initial denaturation at $95^{\circ} \mathrm{C}$ for 1 minute, $55^{\circ} \mathrm{C}$ for 1 minute and finally $72^{\circ} \mathrm{C}$ for 1 minute. The PCR products were checked using agarose gel $1 \%$ and visualized under UV light. PCR products with proper quality (585 bp) of band DNA were sent to 1st BASE DNA Laboratories Sdn Bhd (Malaysia) for sequencing.

\section{Phylogenetic analysis}

The Basic Local Alignment Search Tool (BLAST) (www.ncbi.nlm.nih.gov) was used to determine the closely related fungal species with active fungal isolate S.06.2. A GTR+G+I model with 1,000 bootstrap replications was run in MEGA 7 (Kumar et al. 2016), resulting in a Maximum Likelihood phylogenetic tree of active isolates. The obtained sequences have been deposited to the DNA Data Bank of Japan (DDBJ) with the accession number at www.ddbj.nig.ac.jp.

\section{Identification of the sponge host of the active fungus}

Polyphasic identification methods were used to determine the sponge species. Specimen processing was prepared following method proposed by van Soest et al. (2014). The DNA of the sponge tissue was extracted with DNeasy blood and tissue kit (@Qiagen, Manchester, UK). Moreover, the sequences were determined with two widely molecular markers in sponge barcoding: the mitochondrial cytochrome $c$ oxidase subunit I (COI) gene and the 5' end terminal part of the 28S rRNA gene (C1-D2 domains). The primers are the degenerate version of the Folmer primers as used by Erpenbeck et al. (2016) with PCR-cycles in the 
following configurations: 3 minutes at $94^{\circ} \mathrm{C}$, followed by 30 seconds at $94^{\circ} \mathrm{C}, 35-40$ cycles of 45 seconds at $45^{\circ} \mathrm{C}, 1$ minute at $70^{\circ} \mathrm{C}$, and 5 minutes at $70^{\circ} \mathrm{C}$. The $28 \mathrm{~S}$ primer used were 28S-C2 (forward) and 28S-D2 (reversed) primers, also in accordance with Erpenbeck et al. (2016) with the following configurations: PCR cycles for 3 minutes at $94^{\circ} \mathrm{C}$, followed by 30 seconds at $94^{\circ} \mathrm{C}, 30$ cycles of 20 seconds at $51^{\circ} \mathrm{C}, 1$ minute at $72^{\circ} \mathrm{C}$ and 5 minutes at $72^{\circ} \mathrm{C}$. The PCR products were checked using agarose gel $1.7 \%$ and analyzed on Biorad Gel Documentation. The PCR products were then sent to Macrogen Laboratories (Amsterdam, The Netherlands) for sequencing. Lastly, the sponge species were determined with BLAST, and the marine Porifera database (www.marinespecies.org/porifera) was consulted for morphological identification.

\section{RESULTS AND DISCUSSION}

\section{Collection of marine sponges}

A total of 13 marine sponges were collected from six different sampling locations along the Karimunjawa Islands, Indonesia (Figure 1), with the abundant diversity of these marine sponges displayed in Table 1. Research from (Blunt et al. 2010) has explained that the oceans are home to large quantities of structurally unique natural products that are mainly accumulated in marine macrobes such as invertebrates (e.g., sponges, soft corals, tunicates) and algae. Several of these secondary metabolites have profound pharmacological properties. Sponge host Cinachyrella sp. was previously reported producing cytotoxic and anti-cancer compounds (Nurhayati et al. 2015). However, it is well known that a major obstacle in the ultimate development of most marine natural products is the lack of supply. Research on marine fungi has suffered neglect, despite the fungi being potent producers of secondary metabolites and bioactive substances (Kobayashi and Ishibashi 1993; Lang et al. 2007; Raghukumar 2008; Yu et al. 2008).

\section{Screening of potential antimicrobial activity}

The lists of "serious concern" threats for drug-resistant Streptococcus pneumoniae by the CDC (CDC 2017), and that of "medium priority" by the WHO (WHO 2017) of the urgency of the need for new antibiotics, requires prompt and sustained action to combat and contain this health concern. These lists were drawn up in a bid to guide and promote research and development of new compounds as candidates for drug treatment collected from spongeassociated fungi. Due to this urgency, further investigation of bioactive compounds from marine sponges that led to the discovery of compound anti-MDR $S$. pneumoniae is needed.

A total of 29 sponge-associated fungi were found from 13 different marine sponges species. Nine of 29 fungal isolates showed biological activity defined by the formation of inhibition zones around the fungal colonies (Table 1). Among these fungi, S.06.2 isolate was selected for further analysis as the candidate with the most potential as indicated by the clearest and largest inhibition zone (18.6 $\pm 2.3 \mathrm{~mm})$ against MDR $S$. pneumoniae.

A literature survey covering more than 23,000 bioactive microbial products, i.e., antifungal, antibacterial, antiviral, cytotoxic and immunosuppressive agents, shows that the producing organisms are mainly from the fungal kingdom. Hence, fungi represent one of the most promising sources of bioactive compounds (Brakhage et al. 2004). Fungi derived from marine sources are considered as constituting a vast reservoir of secondary metabolites (Saleem et al. 2007). The fungus S.06.2 is considerable of great interest as a new, promising source of biologically active products for producing chemical diversity of the secondary metabolites.

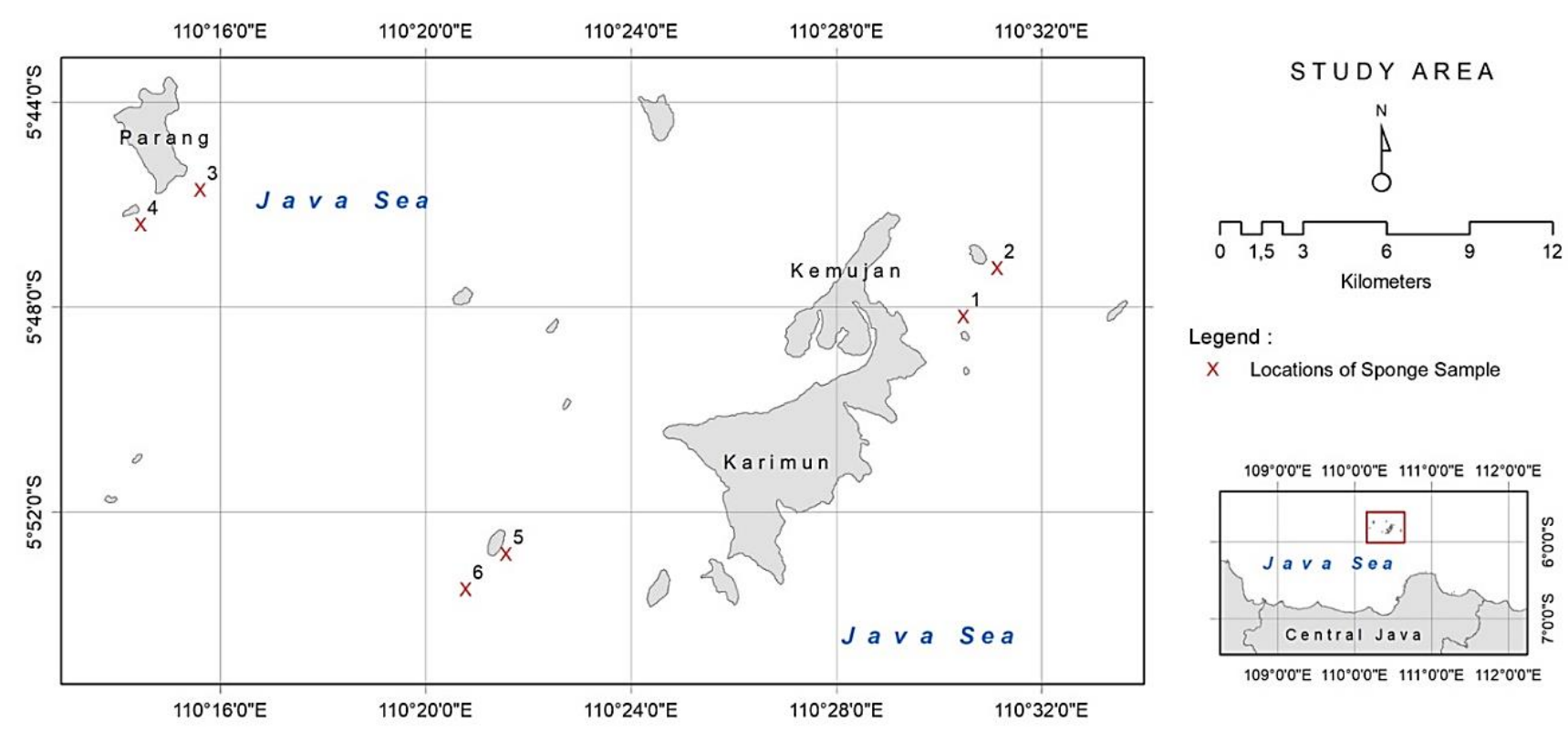

Figure 1. A map of Karimunjawa Islands, Indonesia, showing the location of the sample sites. The image in the lower-right shows the location of the Karimunjawa Islands system in the North Java Sea. Source: GeoEye-1 satellite data from 2014 
Table 1. Screening of sponge-associated fungi against MDR and ATCC $S$. pneumoniae

\begin{tabular}{|c|c|c|c|c|}
\hline \multirow{2}{*}{ Location } & \multirow{2}{*}{$\begin{array}{l}\text { Sponge } \\
\text { sources }\end{array}$} & \multirow{2}{*}{$\begin{array}{l}\text { Fungal } \\
\text { isolates }\end{array}$} & \multicolumn{2}{|c|}{ S. Pneumoniae } \\
\hline & & & ATCC & MDR \\
\hline \multirow[t]{17}{*}{1} & S.16 & S.16.1 & - & - \\
\hline & S.19 & S.19.1 & - & - \\
\hline & & S.19.2 & - & - \\
\hline & & S.19.3 & - & - \\
\hline & & S.19.4 & - & - \\
\hline & & S.19.5 & - & - \\
\hline & & S.19.6 & - & - \\
\hline & & S.19.7 & - & - \\
\hline & & S.19.8 & - & + \\
\hline & & S.19.9 & - & - \\
\hline & & S.19.10 & - & - \\
\hline & & S.19.12 & + & + \\
\hline & & S.19.13 & - & - \\
\hline & S.03 & S.03.1 & - & - \\
\hline & & S.03.2 & - & - \\
\hline & & S.03.3 & - & - \\
\hline & & S.03.4 & - & - \\
\hline 2 & T.14 & Т.14.3 & + & + \\
\hline \multirow[t]{6}{*}{3} & С.06.B & C.06.B & - & - \\
\hline & S.06 & S.06.2* & - & + \\
\hline & C. $10 . \mathrm{B}$ & $\begin{array}{l}\text { C.10.B } \\
(2)\end{array}$ & + & + \\
\hline & S.23 & S.23.1 & - & - \\
\hline & S.28 & S.28.1 & + & - \\
\hline & & S.28.3 & + & - \\
\hline \multirow[t]{3}{*}{4} & C.05.B & C.05.B.1 & + & - \\
\hline & C.08.B & C.08.B & - & - \\
\hline & S.103 & S.103.1 & - & - \\
\hline \multirow[t]{2}{*}{5} & S.55 & S.55.1 & + & - \\
\hline & & S.55.2 & - & - \\
\hline
\end{tabular}

Note: (+) Exhibited antibacterial activity (-) Did not exhibit antibacterial activity (*) Exhibited significant antibacterial activity. No sponge was collected from location 6.

\section{Phylogenetic analysis of active fungal isolate}

Through identification based on the classical taxonomy, including micro and macromorphological features, the isolated fungus S.06.2 was identified as Curvularia lunata.
Phylogenetic inference based on the ITS region revealed that isolate S.06.2 was a member of the genus Curvularia. It clustered together with several species from the genus Curvularia (Figure 3). The DNA sequence of the ITS region of fungal isolate S.06.2 showed 99\% homology. Therefore, C. lunata WJCY01 (KY404177) is the species closest related to isolate S.06.2. The sequence data of isolate S.06.2 has been submitted to GenBank under accession number LC315806.

The isolate S.06.2 and several species of genus Curvularia formed an independent clade with an intrageneric sequence divergence of $2.7 \%$. The presence of generic types of its genus, $C$. lunata, showed that the clade is an authentically of the genus Curvularia. This genus is a sister group of Cochliobulus and is separated by an intergeneric sequence divergence of $7.3 \%$. Furthermore, similarity scores between isolate S.06.2 and Curvularia lunata using BLAST reached as high as $99 \%$. Therefore, fungal isolate S.06.2 can be identified as C. lunata.

In this study, the crude extract EtOAc of fungus Curvularia sp. showed biological activity against human pathogen MDR S. pneumoniae. Marine-derived fungi Curvularia sp. produces anti-inflammatory (Ding et al. 2019), antibacterial (Han et al. 2014, Liu et al. 2019) and anti-cytotoxic (Liu et al. 2019) compounds. Curvularia sp. has also been reported as phytotoxic and as an antifungal metabolite (Yin et al. 2018). Compounds isolated from the EtOAc extract of Curvularia sp. produced new antioxidant and antibacterial compounds (Venkatachalam et al. 2011). New compounds isolated from Curvularia sp., strain M12, were isolated from a leaf (Mondol et al. 2017). Curvularia sp. from red algae Acanthophora spicifera produces a cytotoxic (Greve et al. 2008) which could be a unique resource for the development of new pharmaceuticals. The appearance of an inhibition zone with S.06.2 isolate against MDR $S$. pneumoniae has opened up the possibility for finding an alternative solution to $S$. pneumoniae infections, as the priority list of pathogens will help the case as reported by the CDC to reduce drug-resistant infection per year, excess hospitalizations, deaths and excess medical cost per year around the world (CDC 2017).
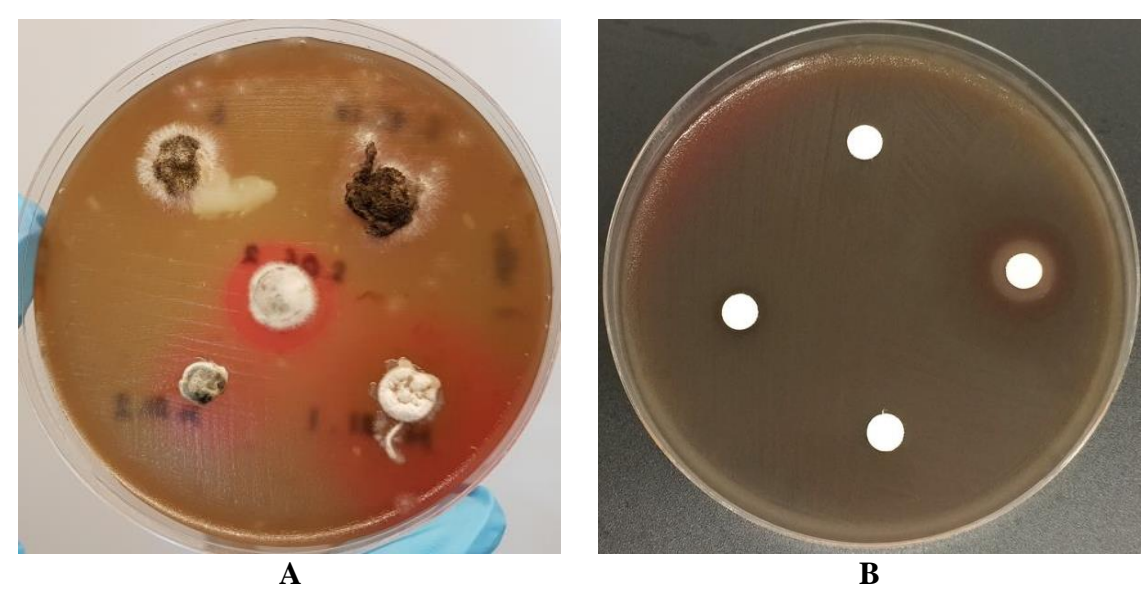

Figure 2. Inhibition zone (Fungi S.06.2 against S. pneumoniae) with the (A) Agar plug method and the (B) Disc-diffusion method. (Photos: O. Cristianawati) 


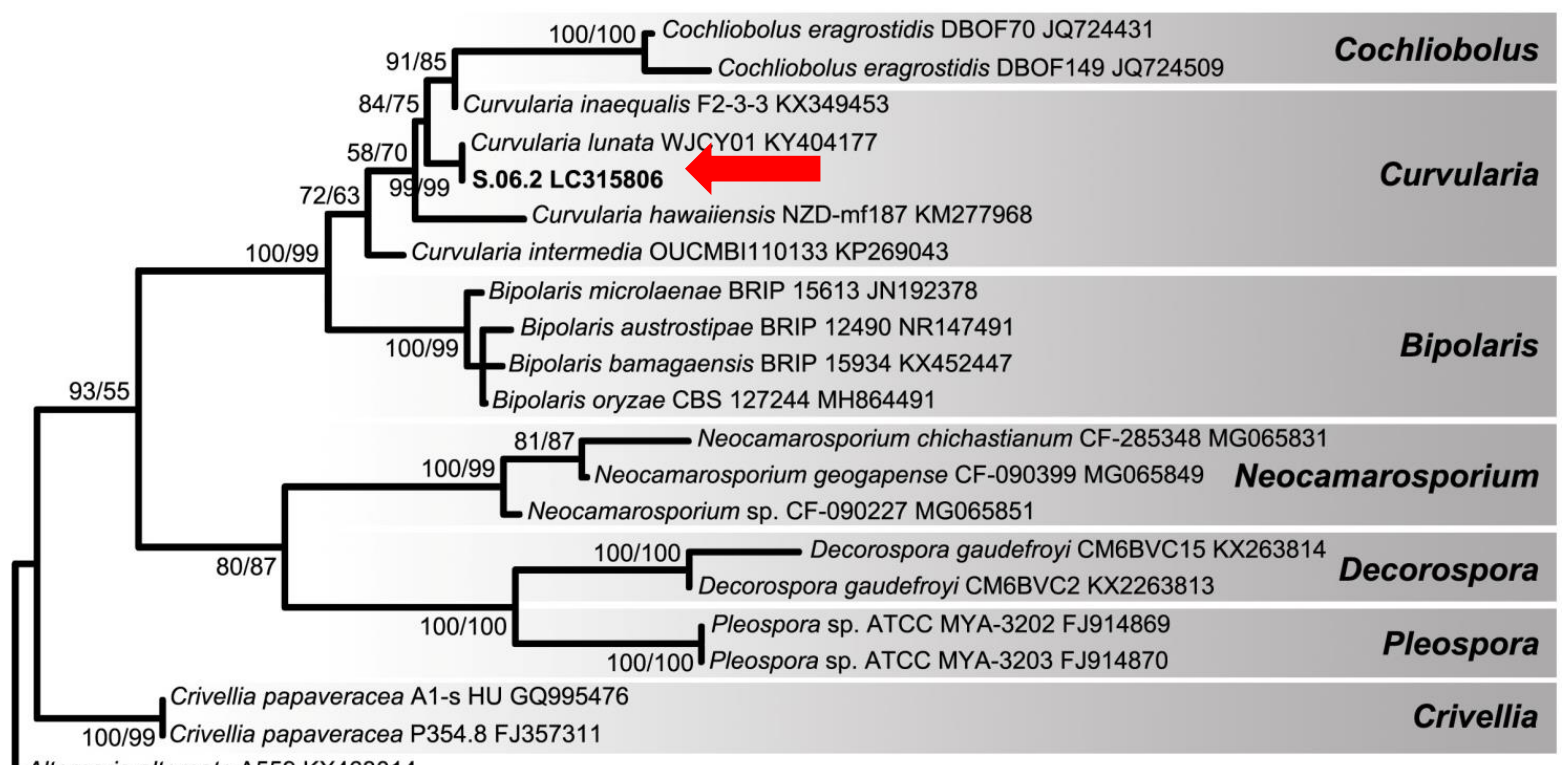

Alternaria alternata A559 KX463014

\subsection{2}

Figure 3. A Maximum Likelihood (ML) phylogenetic tree based on ITS region using GTR+G+I model with 1,000 bootstrap replications. The number of each node indicates bootstrap values (NJ/ML). Bootstrap values below 50\% are not shown. The isolate of sponge-associated fungi is marked in bold letters with a red arrow

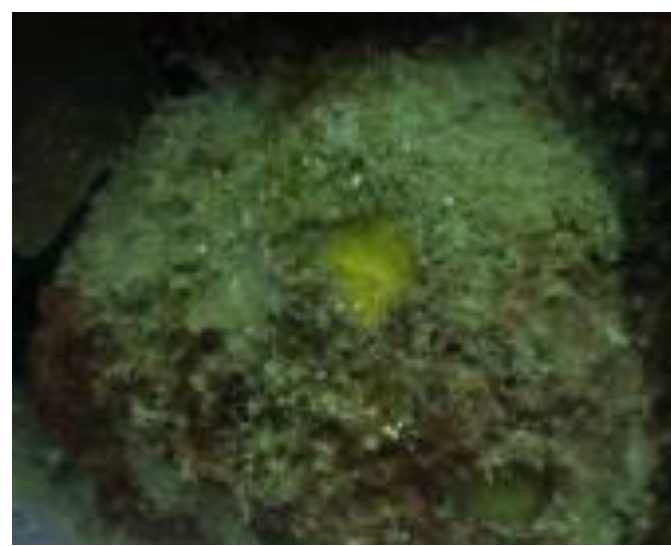

A

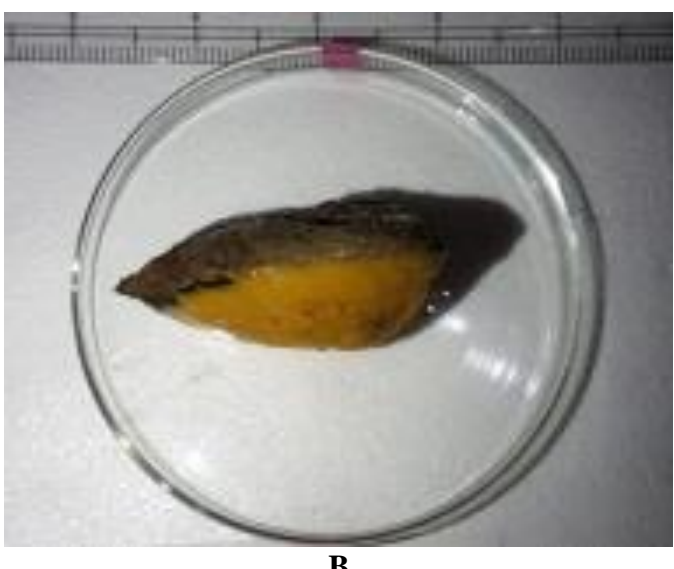

Figure 4. The sponge of species Cinachyrella australiensis with (A) an underwater picture and (B) a surface water picture. (Photos: O. Cristianawati)

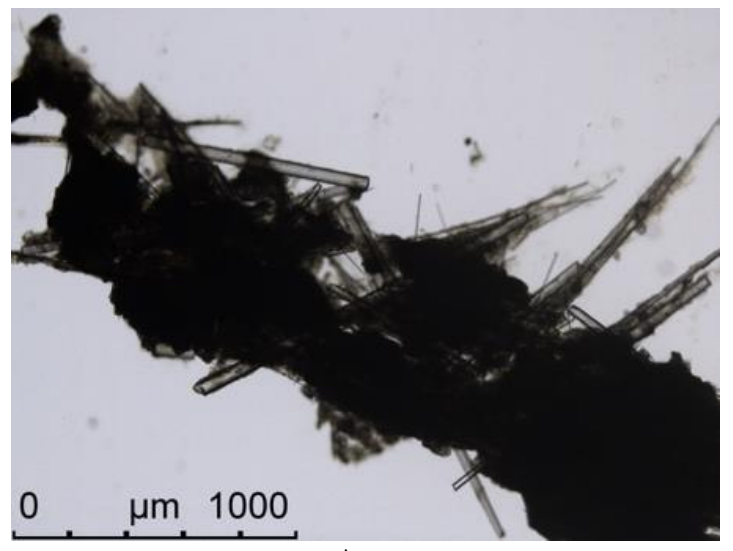

A

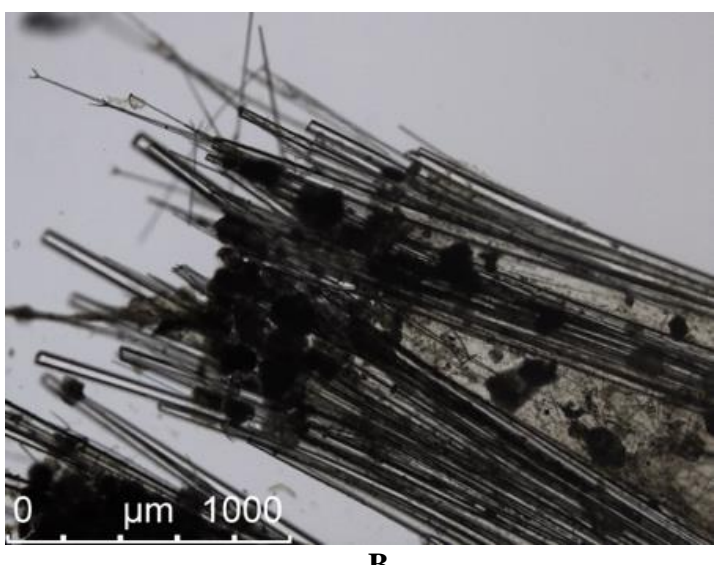

Figure 5. Sections of the Cinachyrella australiensis, namely the (A) Ectosome and the (B) Choanosome consisting of spicules. (Photos: L. E. Becking.) 
Table 2. Level of nucleotide similarity of selected sponge for primer cytochrome $c$ oxidase subunit I and primer 28S

\begin{tabular}{llll}
\hline Sample Code & Sequence Length & Identical Species (bp) & Homology (\%) \\
\hline S.06 & Cinachyrella australiensis voucher QMG 320216 & 819 & 97.32 \\
\hline
\end{tabular}

\section{Identification of sponge hosts}

Combining molecular and morphological data seems to be the most promising approach to a better understanding of phylogenetic relationships (Lafay et al. 1995; Smith et al. 2011). Nucleotide Similarity of Sponge S.06 for CO1 and $28 \mathrm{~S}$ is presented in Table 2. The sponge S.06 was identified as Cinachyrella australiensis. Morphological identification showed that this is globular sponges of max with yellow buds, massive and hispid. It has a distinctly radial form with a pronounced radial orientation of megascleres (Figure 5), as a small basal attachment and almost solid spicule core at the center and the surface part of the sponge S.06 is coated with dark sediment and algae (Figure 4). Ectosome has fewer sigmas than the choanosome and a whitish ectosome layer which is visible with the naked eye (Carter 1886).

The C. lunata S.06.2 isolate was obtained from sponge C. australiensis from location 3 at the Karimunjawa Islands in Indonesia (Figure 1). C. australiensis can usually be found on firm surfaces such as rocks, but some sponges can attach themselves to soft sediment through a root-like base (Van Soest 2019). The morphology of C. australiensis showed one obvious oscule at the top of the sponge.

To the best of our knowledge, the presence of $C$. lunata derived from $C$. australiensis against pathogenic or MDR gram-positive bacteria $S$. pneumoniae in Indonesia has not yet been studied. The $C$. australiensis sponge-associated $C$. lunata fungus produces bioactive compounds that can be used in the treatment of multi-drug resistant respiratory human pathogens $S$. pneumoniae. However, further studies, particularly on bioassay-guided purification and structure elucidation, are needed to determine the anti-MDR $S$. pneumoniae compound.

\section{ACKNOWLEDGEMENTS}

This research was fully funded by a research grant from the Ministry of Research, Technology and Higher Education, Indonesia for PMDSU (Program of Magister Leading to Doctoral Degree for Excellent Under Graduates) scholarship 2015 (315-05/UN7.5.1/PP/2017). Lastly, the author kindly thanks Prof. Gerard Pals of the Amsterdam Universitair Medische Centra, Amsterdam, The Netherlands, who has contributed to improving the presentation of the content of this manuscript. Lastly, the author also thanks Dahlia M Hassell and Sakia Oosterbroek for excellent technical assistance in Marine Animal Ecology laboratory, Wageningen University and Research, The Netherlands. We also thank the PEER Grant for the partially financial support.

\section{REFERENCES}

A Brakhage A, Spröte, Al-Abdallah Q, Gehrke A, Plattner H, Tüncher A. 2004. Regulation of penicillin biosynthesis in filamentous fungi. Adv Biochem Eng/Biotechnol 88: 45-90. DOI: 10.1007/b99257

Blunt JW, Copp BR, Munro MH, Northcote PT, Prinsep MR. 2010. Marine natural products. Nat Prod Rep 27 (2): 165-237. DOI: 10.1039/b906091j.

Bolanos J, De Leon LF, Ochoa E, Darias J, Raja HA, Shearer CA, Miller AN, Vanderheyden P, Porras-Alfaro A, Caballero-George C. 2015. Phylogenetic diversity of sponge-associated fungi from the Caribbean and the Pacific of Panama and their in vitro effect on angiotensin and endothelin receptors. Mar Biotechnol (NY) 17 (5): 533-564. DOI: 10.1007/s10126-015-9634-Z

Buttachon S, May Zin WW, Dethoup T, Gales L, Pereira JA, Silva AM, Kijjoa A. 2016. Secondary metabolites from the culture of the marine sponge-associated fungi Talaromyces tratensis and Sporidesmium circinophorum. Planta Med 82 (9-10): 888-896. DOI: 10.1055/s0042-103687.

Cárdenas P, Rapp HT, Schander C, Tenda OS. 2010. Molecular taxonomy and phylogeny of the Geodiidae (Porifera, Demospongiae, Astrophorida) - combining phylogenetic and Linnaean classification. Zoologica Scripta 39 (1): $89-106$. DOI: $10.1111 /$ j.14636409.2009.00402.x

Carter HJ. 1886. Descriptions of sponges from the neighbourhood of Port Phillip Heads, South Australia J Ann Mag Nat Hist. DOI: 10.1080/00222938609459931

CDC. Centers for Diseases Control. 2017. https: //www.cdc.gov/

Cherazard R, Epstein M, Doan TL, Salim T, Bharti S, Smith MA. 2017. Antimicrobial Resistant Streptococcus pneumoniae: Prevalence, Mechanisms, and Clinical Implications. Am J Ther 24 (3): e361-e369. DOI: 10.1097/MJT.0000000000000551

Chombard C, Boury-Esnault N, Tillier S. 1998. Reassessment of Homology of Morphological Characters in Tetractinellid Sponges Based on Molecular Data. Syst Biol 47 (3): 351-366. DOI: $10.1080 / 106351598260761$

Cleary D, Becking L, de Voogd N, Pires A, Polónia A.M, Egas C, Gomes N. 2013. Habitat- and host-related variation in sponge bacterial symbiont communities in Indonesian waters. FEMS Microbiol Ecol 85 (3). DOI: 10.1111/1574-6941.12135

Corral P, Esposito F, Tedesco P, Falco A, Tortorella E, Tartaglione L, Festa C, D'Auria MV, Gnavi G, Varese GC, de Pascale D. 2018. Identification of a sorbicillinoid-producing Aspergillus strain with antimicrobial activity against Staphylococcus aureus: a new polyextremophilic marine fungus from Barents Sea. Mar Biotechnol (NY). DOI: 10.1007/s10126-018-9821-9

Cristianawati O, Radjasa OK, Sabdono A, Trianto A, Sabdaningsih A, Sibero MT, Nuryadi H. 2017. Exploration of fungal association from hard coral against pathogen MDR Staphylococcus haemolyticus. IOP Conf Ser Earth Environ Sci 55 (1): 012027. DOI: 10.1088/17551315/55/1/012027

Ding Y, An F, Zh X., Yu H, Hao L, Lu Y. 2019. Curdepsidones B (-)G, six depsidones with anti-inflammatory activities from the marinederived fungus Curvularia sp. IFB-Z10. Mar Drugs 17 (5). DOI: 10.3390/md17050266

Ditjen P2P KK. 2018. Health Statistics 2017. http://p2p.kemkes.go.id/wpcontent/uploads/2017/12/LaporanKinerjaDitjenP2P.pdf

DKP-Jateng DKPJT. 2014. Profil Kesehatan Provinsi Jawa Tengah Tahun 2014

//www.depkes.go.id/resources/download/profil/PROFIL_KES_PROV INSI_2014/13_Jateng_2014.pdf

Dunne EM, Mura C, Sudigdoadi S, Fadlyana E, Tarigan R, Indriyani SAK, Pell CL, Watts E, Satzke C, Hinds J, Dewi NE, Yani FF, Rusmil K. Mulholland K., Kartasasmita C. 2018. Carriage of 
Streptococcus pneumoniae, Haemophilus influenzae, Moraxella catarrhalis, and Staphylococcus aureus in Indonesian children: A cross-sectional study. PLoS One 13 (4): e0195098. DOI: 10.1371/journal.pone.0195098

Erpenbeck D, Voigt O, M Al-Aidaroos A, Berumen M, Büttner G, Catania D, Naguib Guirguis A. Paulay G, Schätzle S, Wörheide G 2016, Molecular biodiversity of Red Sea demosponges. Mar Poll Bull 105 (2). DOI: 10.1016/j.marpolbul.2015.12.004

Farida H, Severin JA, Gasem MH, Keute M, Wahyono H, van den Broek P, Hermans PW, Verbrugh HA. 2014. Nasopharyngeal carriage of Streptococcus pneumonia in pneumonia-prone age groups in Semarang, Java Island, Indonesia. PLoS One 9 (1): e87431. DOI: 10.1371/journal.pone.0087431

Folmer O, Black M, Wr H, Lutz R, Vrijenhoek R. 1994. DNA primers for amplification of mitochondrial Cytochrome $\mathrm{C}$ oxidase subunit I from diverse metazoan invertebrates. Mol Mar Biol Biotechnol 3 (5): 294 299.

Greve H, Schupp PJ, Eguereva E, Kehraus S, Kelter G, Maier A, Fiebig HH, Konig GM. 2008. Apralactone A and a new stereochemical class of curvularins from the marine-derived fungus Curvularia sp. European J Org Chem 2008 (30). DOI: 10.1002/ejoc.200800522

Hajaj B, Yesilkaya H, Shafeeq S, Zhi X, Benisty R, Tchalah S, Kuipers OP, Porat N. 2017. CodY regulates thiol peroxidase expression as part of the pneumococcal defense mechanism against $\mathrm{H}_{2} \mathrm{O}_{2}$ stress Front Cell Infect Microbiol 7, 210. DOI: 10.3389/fcimb.2017.00210

Ha WB, Lu YH, Zhang H, Zhang GF, Mei YN, Jiang N, Lei X, Song C, Ng SW, Ta RX. 2014. Curvulamine, a new antibacterial alkaloid incorporating two undescribed units from a Curvularia species. Org Lett 16 (20): 5366-5369. DOI: 10.1021/o1502572g

Hu J, Su X, Huang Z, Wagner L, Carlson B, Yan J, Tang S, Li, Boulton ML, Yuan Z. 2016. Streptococcus pneumoniae and Haemophilus influenzae type b carriage in Chinese children aged 12-18 months in Shanghai, China: a cross-sectional study. BMC Infect Dis 16, 149. DOI: $10.1186 / \mathrm{s} 12879-016-1485-3$

Imhoff JF. 2016. Natural products from marine fungi--still an underrepresented resource. Mar Drugs 14 (1): $19 . \quad$ DOI $10.3390 / \mathrm{md} 14010019$

Indraningrat AA, Smidt H, Sipkema D. 2016. Bioprospecting spongeassociated microbes for antimicrobial compounds. Mar Drugs 14 (5) DOI: $10.3390 / \mathrm{md} 14050087$

Kadioglu A, Weiser JN, Paton JC, Andrew PW. 2008. The role of Streptococcus pneumoniae virulence factors in host respiratory colonization and disease. Nat Rev Microbiol 6 (4): 288-301. DOI: 10.1038/nrmicro1871

Khoeri M, Radjasa OK, Sabdono A, Sudoyo H. 2011. Bioprospecting of bacterial symbiont of tunicate Didemnum molle from Sambangan, Karimunjawa Islands. J Coast Dev 14 (3): 255-261

Kumar, S., Stecher, G., Tamura, K. (2016) MEGA7: Molecular Evolutionary Genetics Analysis Version 7.0 for Bigger Datasets. Mol Biol Evolution 33 (7): 1870-1874. DOI: 10.1093/molbev/msw054\%20

Kobayashi J, Ishibash M. 1993. Bioactive metabolites of symbiotic marine microorganisms. Chemical Reviews 93 (5): 1753-1769. DOI: 10.1021/cr00021a005

Lafay B, Smith AB, Christen R. 1995. A combined morphological and molecular approach to the phylogeny of asteroids (Asteroidea: Echinodermata). Syst Biol 44 (2): 190-208. DOI 10.1093/sysbio/44.2.190

Lang G, Wiese J, Schmaljohan R, Imhoff J. 2007. New pentaenes from the sponge-derived marine fungus Penicillium rugulosum: Structure determination and biosynthetic studies. ChemInform 39 (10). DOI: 10.1002/chin.200810232

Le HL, Lecointre G, Perasso R. 1993. A 28S rRNA-based phylogeny of the gnathostomes: first steps in the analysis of conflict and congruence with morphologically based cladograms. Mol Phylogenet Evol 2 (1): 31-51. DOI: 10.1006/mpev.1993.1005

Lestari ES, Severin JA, Verbrugh HA. 2012. Antimicrobial resistance among pathogenic bacteria in Southeast Asia. Southeast Asian J Trop Med Public Health 43 (2): 385-422.

Liu WH, Ding Y, Ji X, An FL, Lu YH. 2019. Curvulaide A, a bicyclic polyketide with anti-anaerobic bacteria activity from marine-derived Curvularia sp. J Antibiot (Tokyo) 72 (2): 111-113. DOI: 10.1038/s41429-018-0110-7

Mayer AM, Rodriguez AD, Taglialatela-Scafati O, Fusetani N. 2013 Marine pharmacology in 2009-2011: marine compounds with antibacterial, antidiabetic, antifungal, anti-inflammatory, antiprotozoal, antituberculosis, and antiviral activities; affecting the immune and nervous systems, and other miscellaneous mechanisms of action. Mar Drugs 11 (7): 2510-2573. DOI: 10.1016/j.bbagen.2009.03.011

Mirza S, Wilson L, Benjamin WH, Jr, Novak J, Barnes S, Hollingshead SK, Briles DE. 2011. Serine protease PrtA from Streptococcus pneumoniae plays a role in the killing of $S$. pneumoniae by apolactoferrin. Infect Immun 79 (6): 2440-2450. DOI: 10.1128/IAI.00489-10

Mondol MA, Farthouse J, Islam MT, Schuffler A, Laatsch H. 2017. Metabolites from the endophytic fungus Curvularia sp. M12 act as motility inhibitors against Phytophthora capsici zoospores. J Nat Prod 80 (2): 347-355. DOI: 10.1021 /acs.jnatprod.6b00785

Nurhayati APD, Pratiwi R, Wahyuono S, Istriyati I, de Voogd N. 2015. The anticancer activity of marine sponge Cinachyrella sp. (Family Tetillidae). IPTEK, The Journal for Technology and Science 25: 3. DOI: $10.12962 / j 20882033 . v 25 i 3.530$

O'Brien KL, Wolfson LJ, Watt JP, Henkle E, Deloria-Knoll M, McCall N, Lee E, Mulholland K, Levine OS, Cherian T. 2009. Burden of disease caused by Streptococcus pneumoniae in children younger than 5 years: global estimates. Lancet 374 (9693): 893-902. DOI: 10.1016/S0140-6736 (09)61204-6

Qiu WY, Yao YF, Zhu YF, Zhang YM, Zhou P, Jin YQ, Zhang B. 2005. Fungal spectrum identified by a new slide culture and in vitro drug susceptibility using Etest in fungal keratitis. Curr Eye Res 30 (12): 1113-1120. DOI: $10.1080 / 02713680500423671$

Radjasa OK, Khoeri MM, Darusallam CC, Trimasanto H, Sudoyo H. 2013. Bacterial symbionts of reef invertebrates: Screening for antipathogenic bacteria activity. Biodiversity 14 (2). DOI: $10.1080 / 14888386.2013 .774937$

Raghukumar C. 2008. Marine fungal biotechnology: An ecological perspective. Fungal Diversity $31 . \quad$ http: //www.fungaldiversity.org/fdp/sfdp/31-2.pdf

Rahaweman AC, Pamungkas J, Madduppa H, Thoms C, Tarman K. 2016. Screening of endophytic fungi from Chlorophyta and Phaeophyta for antibacterial activity. IOP Conf Ser Earth Environ Sci 31 (1): 012026. DOI: $10.1088 / 1755-1315 / 31 / 1 / 012026$

Sabdaningsih A, Cristianawati O, Sibero MT, Nuryadi H, Radjasa OK, Sabdono A, Trianto A. 2017. Screening antibacterial agent from crude extract of marine-derived fungi associated with soft corals against MDR-Staphylococcus haemolyticus. IOP Conf Ser Earth Environ Sci 55 (1): 012026. DOI: 10.1088/1755-1315/55/1/012026

Safari D, Harimurti K, Khoeri MM, Waslia L, Mudaliana S, A'Yun H Q, Angeline R, Subekti D. 2015. Staphylococcus aureus and Streptococcus pneumoniae Prevalence among Eldery Adults in Jakarta, Indonesia. Southeast Asian J Trop Med Public Health 46 (3): 465-471.

Saleem M, Shaiq Ali M, Hussain S, Jabbar A, Ashraf M, Sup Lee Y. 2007. ChemInform Abstract: Marine natural products of fungal origin. ChemInform 39 (1): DOI: 10.1002/chin.200801273

Sibero MT, Sabdaningsih A, Cristianawati O, Nuryadi H, Radjasa OK, Sabdono A, Trianto A. 2017. Isolation, identification and screening antibacterial activity from marine sponge-associated fungi against Multidrug-Resistant (MDR) Escherichia coli. IOP Conf Ser Earth Environ Sci 55 (1): 012028. DOI: 10.1088/1755-1315/55/1/012028

Sibero MT, Igarashi Y, Radjasa OK, Sabdono A, Trianto A, Zilda DS, Jati Wijaya Y. 2019. Sponge-associated fungi from a mangrove habitat in Indonesia: species composition, antimicrobial activity, enzyme screening and bioactive profiling. Intl Aquat Res. DOI: 10.1007/s40071-019-0227-8

Smith AB, Paterson GLJ, Lafay B. 2011. Ophiuroid phylogeny and higher taxonomy: morphological, molecular and palaeontological perspectives. Zool J Linn Soc 114 (2): 213-243. DOI: 10.1006/zjls.1995.0024

Strobel G, Daisy B. 2003. Bioprospecting for microbial endophytes and their natural products. Microbiol Mol Biol Rev 67 (4): 491-502. DOI: 10.1128/MMBR.67.4.491-502.2003

Trianto A, Sabdono A, Rochaddi B, Desy A, Triningsih D. 2017. Exploration of marine sponges-associated fungi producing antifungal compounds. Asian J Microbiol Biotech Env Sci 19 (3): 588-593.

Trianto A, Radjasa OK, Pribadi R, Widyaningsih S, Wittriansyah K, Yusidharta I, Riniatsih I. 2017. Isolation and identification of spongeassociated fungus producing anti multidrug-resistant (MDR) bacterial substances. Res J Pharmaceut Biol Chem Sci 8 (6).

van Soest R, Meesters E, Becking L. 2014. Deep-water sponges (Porifera) from Bonaire and Klein Curaçao, Southern Caribean. Zootaxa 3878 (5): 401-443. DOI: 10.11646/zootaxa.3878.5.1 
Van Soest RWMBE, Hooper JNA, Rützler K, de Voogd J, Alvarez, B, Hajdu E, Pisera B, Manconi, R, Schönberg C, Klautau M, Picton B, Kell M, Vacelet J, Dohrman M, Díaz, MC, Cárdenas P, Carballo JL, Ríos P, Downey R. 2019. World Porifera Database. Cinachyrella Wilson, 1925 http://www.marinespecies.org/porifera/porifera.php?p=taxdetails\&id= 171287 [2019-07-12]

Vasanthabharathi V. 2012. Bioactive potential of symbiotic bacteria and fungi from marine sponges. African J Biotechnol 11 (29). DOI: 10.5897/AJB11.1378

Venkatachalam G, Ambayeram V, Suryanarayanan T, Doble M. 2011 Isolation and characterization of new antioxidant and antibacterial compounds from algicolous marine fungus Curvularia tuberculata. Conference: 2011 International Conference on Bioscience, Biochemistry and Bioinformatics (ICBBB 2011). Feb 26, 2011 - Feb 28, 2011, Sentosa, Singapore. IACSIT Press, Singapore.

Vicente J, Stewart A, Song B, Hill RT, Wright JL. 2013. Biodiversity of Actinomycetes associated with Caribbean sponges and their potential for natural product discovery. Mar Biotechnol (NY) 15 (4): 413-424. DOI: 10.1007/s10126-013-9493-4

Volgraf M, Lumb JP, Brastianos HC, Carr, Chung MK, Munzel M, Mauk AG, Andersen RJ, Trauner D. 2008. Biomimetic synthesis of the IDO inhibitors exiguamine A and B. Nat Chem Biol 4 (9): 535-537. DOI: 10.1038/nchembio. 107 von Rintelen K, Arida E, Häuser C. 2017. A review of biodiversity-related issues and challenges in megadiverse Indonesia and other Southeast Asian countries. Research Ideas and Outcomes 3 (1): e20860DOI: 10.3897/rio.3.e20860

WHO. 2017. WHO publishes list of bacteria for which new antibiotics are urgently needed.

Wittriansyah K, Trianto A, Widyaningsih S, Radjasa OK, Pribadi R. 2016. Screening of antibacterial MDR derived from sponge-associated fungus of Riung Water, Nusa Tenggara Timur. Ilmu Kelautan 21 (4): 197-202. DOI: 10.14710/ik.ijms.21.4.197-20

Yin C, Jin L, Sun F, Xu X, Shao M, Zhang Y. 2018. Phytotoxic and antifungal metabolites from Curvularia crepinii QTYC-1 isolated from the gut of Pantala flavescens. Molecules (Basel, Switzerland) 23 (4): 951. DOI: 10.3390/molecules23040951

Yu Z, Lang G, Kajahn I, Schmaljohann R, Imhoff JF. 2008. Scopularides $\mathrm{A}$ and $\mathrm{B}$, cyclodepsipeptides from a marine sponge-derived fungus, Scopulariopsis brevicaulis. J Nat Prod 71 (6): 1052-1054. DOI: 10.1021/np070580e

Yuliarti K, Hadinegoro S, Supriyatno B, Karuniawati A. 2012. Invasive pneumococcal disease among hospitalized children aged 28 days to 60 months in Jakarta. Southeast Asian J Trop Med Public Health 43 (1): $136-144$ 